\title{
Analysis of The Resilience Conditions of Individual, Family, and Community during The Covid-19 Pandemic
}

\author{
Viena Rusmiati Hasanah ${ }^{1 *}$, Gumpanat Boriboon ${ }^{2}$, \\ Yoyoh Jubaedah ${ }^{1}$, Hodijah Wulandari ${ }^{1}$
}

${ }^{1}$ Universitas Pendidikan Indonesia, Indonesia

${ }^{2}$ Srinakharinwirot University, Thailand

*Email: viena@upi.edu

Submitted: 20 December 2020. Revised: 31 January 2021. Accepted: 13 February 2021

\begin{abstract}
The COVID-19 pandemic outbreak, a disaster that shocked the whole world, has affected various aspects of people's lives, including the resilience of society, especially the poor. This study aims to see the condition of the resilience of the poor in Bandung in facing the COVID-19 pandemic. The survey method was chosen to obtain the latest data flexibly with a total of 200 respondents, through the distribution of a questionnaire of 40 items consisting of aspects of individual, family, and community resilience. The results show that individual resilience is very dominant during the COVID-19 pandemic disaster, this mutually affects family resilience and community resilience. The most dominant factor in the resilience of individuals and families is the factor of spirituality and optimism in facing this epidemic, the factors that affect community resilience are individual interactions in community activities in the security, social and religious fields
\end{abstract}

Key words: Individual Resilience, Family Resilience, Community Resilience, COVID-19

How to Cite: Hasanah, V. R., Boriboon, G., Jubaedah, Y., \& Wulandari, H.. (2021). Analysis of The Resilience Conditions of Individual, Family, and Community during The Covid-19 Pandemic. Journal of Nonformal Education, 7(1), 94-102.

DOI: http://dx.doi.org/10.15294/jne.v7i1.27853

\section{INTRODUCTION}

The COVID-19 pandemic outbreak has shocked all people on earth. This outbreak began to spread around the world in early 2020 (CNBC, 2020). This outbreak occurred suddenly and changed people's behavior drastically due to restrictions put in place to prevent the spread of the virus (Yunus et al., 2020). The government has implemented Large-Scale Social Restrictions (PSBB) as an effort to discipline the community in carrying out activities and interactions outside the house (detik.com, 2020). This causes the majority of people to stay at home so that new terms emerge, such as work from home, school from home, and so on. This policy has had a tremendous impact on all aspects of people's lives. Education, social and economic sectors have been impacted significantly (Tapung et al.,, 2020). Inequality, poverty and education are the pathways most affected by this pandemic because they reduce the income of the vulnerable and the poor (Hidayatullah et al., 2020). The education sector made major changes in carrying out learning patterns and teaching and learning activities of various levels of educational institutions. The social sector has an impact on community interaction patterns that have changed drastically. Almost all types of interactions are carried out online. The economic sector has had a tremendous impact on large and small business sectors so that it indirectly impacts the economy of the society en masse. This condition has defi- nitely increased the poverty rate (detik.com, 2020). State policies should support the possibility of flexible work practices (macro-environmental level) and provide services that oversee family interactions (relationship level) and personal well-being (individual level) (Salin et al., 2020). In addition, the outbreak and the PSBB policy have had a considerable influence on the physical health and mental health of the community (Ho et al., 2020), public health and the environment, (Tsai \& Wilson, 2020) lifestyle and communication (Dani, et al., 2020). The Influences at the individual level is in form of depression, anxiety, confusion, fear, and anger that have an impact on the family (Ramadhana, 2020). The closure of schools and the shift to distance learning have sizable implications not only for material mastery but also for their mental health, some suggest that mental illness is the second wave of the COVID-19 pandemic. High stress levels given rampant fear of illness and death, economic security, feelings of great distress to society (Luthar et al., 2020). The acute disease outbreak, due to various pressures, is likely to shift from the medical disaster COVID-19 to an economic impact (Barzilay et al., 2020). The impact of COVID on the family is the global monetary crisis, the decline in the family level, and the need for additional expenses for health costs (Irawaty, 2020).

At the end of 2020, it is predicted that the average poverty rate in Indonesia will reach $9.7 \%$. There are about 2.8 million people who have lost their jobs, the 
projected result of this pandemic is that at least 5.2 million people will lose their jobs (Marpaung et al., 2020). The weakening global economic growth has had many impacts on the economic pace in Indonesia, both in terms of trade, investment and tourism. Thus, changes in projected economic growth have become slower due to the spread of Covid-19 (Hidayatullah et al., 2020). The drastic decline in economic conditions will greatly affect various aspects of people's lives, unexceptionally the people of Bandung city. The number of people affected by the COVID-19 pandemic was 1.112 confirmed cases as of 21/09/2020 (Pusicov, 2020). The number of cases has certainly made the Bandung City Government implement a social restriction policy to prevent an increase in Corona cases. This will certainly affect various aspects of the life of the people of Bandung. Family, social, economic, educational, and other conditions will encounter changes in different conditions from the previous. Family experiences about pandemics are not the same. Physical and mental health basics, state and local policy decisions, race and / or ethnicity, economic bloc, individual and community resources, immigration status, and geography all influence the relationship between COVID-19 and well-being (Coller \& Webber, 2021). Therefore, this research aims to uncover the resilience condition of the people of Bandung city during the COVID-19 Pandemic judging by the resilience of individuals, families, and communities. When the COVID-19 pandemic hit the world, Indonesian families were affected by various impacts from the existence of the virus, ranging from family health problems, family economy, family harmony, family social psychology, socio-culture, and others (Kasdi \& Saifudin, 2020). Resilience describe how individual Resilience describes how individuals use resources to solve problems that make them stressed and uncomfortable with the ability to effectively adapt existing resources to manage the situation (Antonio et al., 2020).

Individual resilience in dealing with the COVID19 outbreak is needed. Diverse information that comes in through various media will greatly affect a person's perception of COVID-19. Some of the residents obey the information and ways to prevent the spread of COVID-19 but some do not, this bias occurs because the public is not getting the right information (Barua et al., 2020). Resilience is defined as a positive adaptation when addressing threats and discomfort. Efforts to improve resilience skills are focused on problem-solving skills, social-emotional learning, maintaining healthy relationships with parents, friends, and spouses, and strengthening executive and regulatory functions in the community system (Yates et al., 2015). Individual indicators of resilience include 1) personal control, 2) self-efficacy, 3) belief, 4) spirituality, 5) emotional regulation, 6) effective skills, and 7) a positive outlook (Distelberg, et.al, 2015). The strategies for maintaining resilience seen from the health approaches are divided into 3 strategies: 1) gratification (connection and communication, meaning and purpose), 2) resilience in building practice (self-reflection, time for yourself, compassion, spirituality, 3) useful (acceptance, flexibility, selfawareness) (Gogo et al., 2019).

As for family resilience, which is a collection of the resilience of individuals in the smallest group in society, it is defined as the ability to overcome problems in the family and adapt to these abilities. There are 3 minimal aspects of family resilience i.e. physical resilience which includes the needs for clothing, food, shelter, education, and health 2) social resilience oriented to religious values, effective communication, and family commitment, 3) psychological resilience which includes the ability to overcome problems, control emotions, self-concept, and caregiving for family members (Uyun Muhamad, 2020). Familycentered assessment systems can lead to individual, family, and/or group work with young people, parents, and significantly extended family members (Walsh, 1996). The indicators of family resilience during the COVID 19 Pandemic include family economic pressures, stress symptoms, food coping strategies, family problems and strategies, psychological well-being, social welfare, family resilience (Sunarti et al., 2003)

Individual resilience and good family resilience will lead to good community resilience. Community resilience means the ability of the communities to utilize collective and institutional resources to deal with and adapt to changes faced during and after a disaster. Community resilience emerges from 4 adaptive capacities such as economic development, social capital, information and communication, and community competence (French Red Cross, 2008). Community resilience refers to the conditions of interaction between individuals and their communities and refers to the success of society in meeting the needs of its members, and support between individuals in it (Kimhi et al., 2020). It needs to be realized that resilience does not only exist at the individual level, but also at the community level. In any societal ecosystem, there is a level of shared resilience necessary to overcome the stress of the coronavirus pandemic and restore normal function (Vinkers et al., 2020). Under these conditions, all are in the same general difficulty, thus giving us a certain degree of control. At the same time, governments, politicians, and decision makers are subject to an uncontrolled threat - both from a health perspective, and from an economic point of view (Vinkers et al., 2020). 


\section{METHODS}

This study uses survey methods to obtain data from a topic flexibly from events in a particular condition with cross-sectional survey type (NavarroRivera \& Kosmin, 2013). The survey was conducted in July 2020 for 1 month during the COVID-19 Pandemic in Bandung, while the target of this study was the poor people of Bandung. This is done to find out the extent of the resilience of the poor in dealing with the covid-19 pandemic that came suddenly. Sampling is done through a non-probability random sampling method with a total of 200 respondents. Surveys are conducted directly by following health protocols. The survey was conducted through a questionnaire of 40 items on aspects of individual resilience, family resilience, and community resilience. Data analysis is performed using Microsoft excel by calculating the percentage of each item and the aspect asked to be subsequently interpreted.

\section{RESULTS AND DISCUSSION}

The citizens of Bandung City have to be able to adapt to new living habit during the COVID-19 Pandemic. Adaptation can occur either as a response or anticipation of a crisis. Even though the degree of adaptation of each individual is different, under these conditions it will be obvious the difference in their adaptability. Adaptation is closely related to the condition of the ability to survive in various conditions. Any adaptation must enhance the community, that is, it must produce a positive result (positive trajectory) for its situation after experiencing difficulties (Eachus, 2014). Because this pandemic has confirmed the precarious and interdependent relationship between health and the economy in the context of disease outbreaks (Etienne et al., 2020). Although the level of adaptation of each individual is different, in these conditions their adaptability will obviously be noticed. Adaptation is closely related to the condition of survival ability in various conditions. Resilience is defined as a positive adaptation in dealing with threats and discomfort (Yates et al., 2015). The resilience of the community means the ability of the community to utilize collective and institutional resources to face and adapt to the changes faced during and after the disaster (French Red Cross, 2008). The COVID 19 outbreak is stated to be a disaster as it greatly affects various aspects of life. The condition of community resilience from individual, family and community aspects in Bandung City during the COVID 19 Pandemic is illustrated in the Figure 1.

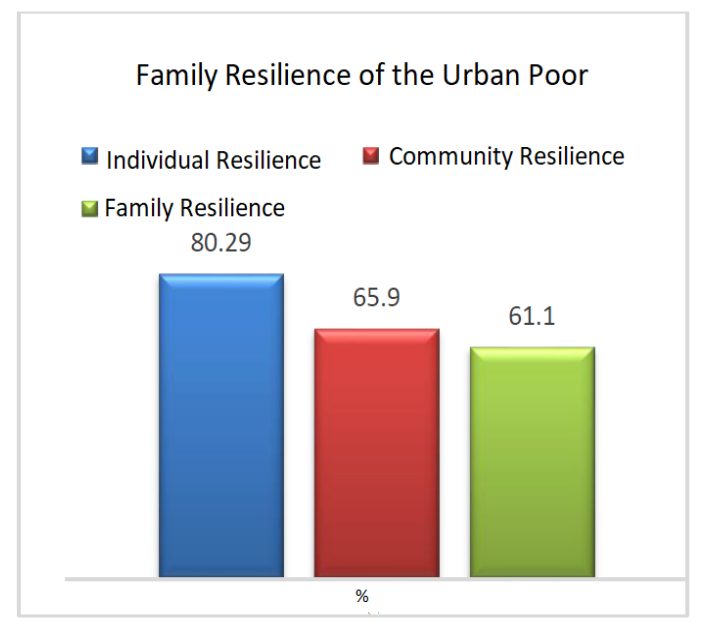

Figure 1. Resilience Conditions of the Urban Poor

The Figure 1 shows the results of data processing of resilience conditions in the overall urban poor economy that include aspects of individual resilience, family resilience, and community resilience. Individual resilience showed the highest yield of $80,29 \%$. The family resilience percentage was $65.9 \%$, and the lowest was community resilience of $61.1 \%$. The resilience of the community is certainly the result of the accumulation of resilience of the existing poor families. Family resilience accumulates from the resilience of individuals in each family. The result of the percentage of community resilience is the least due to the indicator of community resilience emerge from 4 adaptive capacities i.e. economic development, social capital, information and communication, and community competence (French Red Cross, 2008), so that the resilience indicator is very complex compared to the indicators in individual and family aspects. As for the strategies that can be carried out to maintain resilience, both the resilience of individuals, families, and communities seen from the approach of health is divided into 3 strategies: 1) gratification (connection and communication, meaning and purpose), 2) resilience in building practice (self-reflection, time for self, compassion, spirituality, 3) useful attitudes (acceptance, flexibility, self-awareness) (Gogo et al., 2019). The strategy of maintaining and fostering resilience in terms of health is built with the existence of good relationships between individuals and families, acceptance, awareness and adaptive to existing changes, and accompanied by a strong spirituality from each member of society. Therefore, it is necessary to understand and strengthen the community regarding this strategy. The survey results in the chart above show that individual resistance gets the highest percentage compared to other resistance conditions. The explanation of each aspect will be described in detail in the Figure 2. 


\section{Individual Resilience}

Resilience is a highly critical protective ability in the physical processing of various influences of the surrounding environment emotionally, cognitively or physically challenged (Gogo et al., 2019). The ability to manage the various influences that come in order to survive to deal with all influences from outside the individual. Resilience is an individual skill that can be trained and controlled by the individual. The indicators of individual resilience include: 1) personal control, 2) self-efficacy, 3) belief, 4) spirituality, 5) emotional regulation, 6) effective skills, and 7) a positive outlook(Distelberg, et.al, 2015). The indicators of individual resilience are related to self-management internally and externally, as individual efforts to control attitudes and behavior. Other theorists argue that resistance studies should take environmental and biological factors into account. Internal and external factors that can contribute to or prevent resilience at the individual level and implicitly at the family level. Internal (i.e., genetic) factors are generated in a person (Hooper, 2017). Experts argue that resilience is greatly influenced by several things, namely 1) good interpersonal relationships, 2) social relationships and self-confidence to continue to expand relationships with other individuals, 3) having internal resources such as optimism and positive thinking, and 4) spirituality high (Wahyudi et al., 2018). The condition of the individual resilience of the poor in Bandung is illustrated in Figure 2.

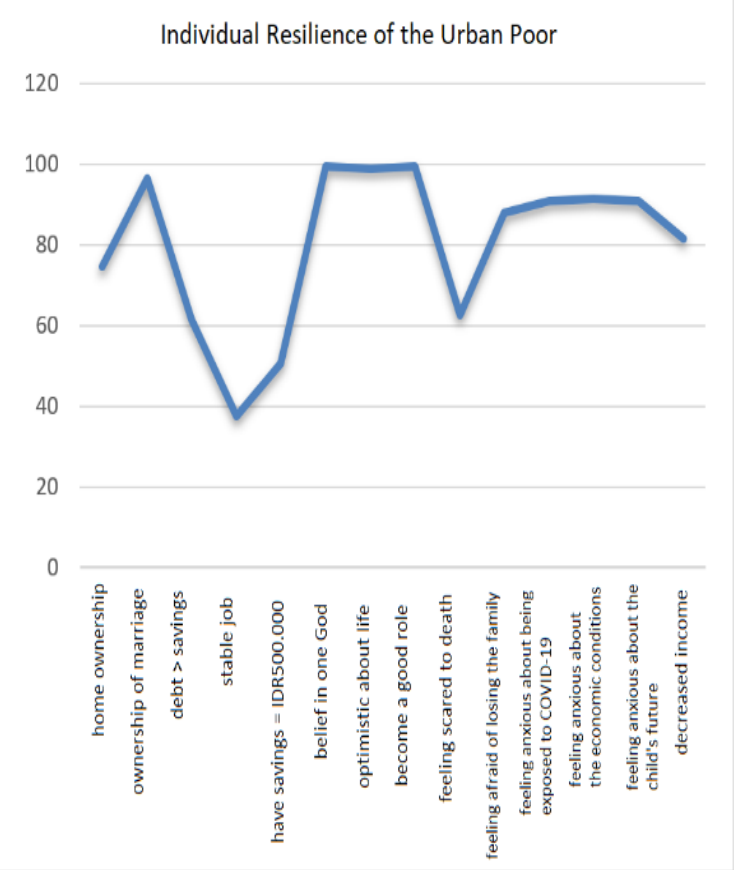

Figure 2. Individual Resilience of the Urban Poor

The individual resilience graph above shows that there are several of individual resilience indicators that get the greatest results, including belief in God Almighty, being optimistic in life, and being able to be a good role model as an individual. Each of the three indicators get the largest percentage of $99 \%$. According to Eshel \& Kimhi (2016) personality capacity tends to change due to changes in the balance of protective factors and individual risk has advantages over resilience control such as optimism. The percentage of resilience of individuals that get the greatest value is driven by spiritually strong beliefs and the strength of optimism from individuals in Bandung City. This caused them to survive even in the condition of covid-19 pandemic which make the poor collapsed in Bandung. The percentage of this indicator is followed by the ownership of the marriage administration of $96.5 \%$. However, as considerable percentage of the results also occurred in individual anxiety indicators, including covid-19 anxiety, economic anxiety, and anxiety of future children's condition by $91 \%$. It was followed by an $88 \%$ fear of losing a family. Indicators that affect the psychological condition of individuals are quite high, this is natural because of the information they get came from various media of the government as well as non-government agencies. This leads to information bias so that the public does not get proper information (Barua et al., 2020). The percentage of people real condition decreased by income of $81.5 \%$. Although as many as $74.5 \%$ of the community owns a house. A total of $62.5 \%$ of the public were afraid to die. $61.5 \%$ of citizen has debt lesser than income. As many as $50.5 \%$ of people have savings of at least IDR.500.000. Meanwhile, the lowest gain was in stable job indicators was only $37.5 \%$.

This shows that the condition of individual resilience is strongly influenced by confidence and optimism in living a life that lead to a better results than the anxieties felt during the COVID-19 Pandemic. Positive and negative influences have implications for health and well-being over time, positive influences produce action, motivation, social relationships and cognitive flexibility, whereas negative influences can result in actions such as avoidance, assault, or expulsion (Janssen et al., 2020). A person who has positive emotions can adapt well to difficult situations, things that can be done to cause positive emotions i.e. by doing at home entertainment activities, chatting with family members and other activities (Buana, 2020), although various psychological and economic factors are quite burdensome to the condition of the individual's resilience, this can be reduced by doing fun activities with family members. Therefore, individual resilience is closely related to family resilience.

\section{Family Resilience}

Family becomes the first social environment to introduce love, religious morals, and socio-culture. The family is also the main defense that can ward off various negative influences from existing social dynamics (Kasdi \& Saifudin, 2020). A strong family is the main 
component of a strong community, which contributes to the strength of society at large, as society changes, the family faces increasingly diverse challenges (Isaacs et al., 2020). Therefore, the family must have a strong endurance. Family resilience, which is a collection of the individuals resilience in the smallest group in society, is defined as the ability to overcome problems in the family and adapt to those abilities. The family systems perspective extends attention to resources for individual resilience across networks of family relationships. The concept of family resilience refers to the family as a functional system, influenced by events and social contexts that are very stressful, and in turn, facilitates the positive adaptation of all members and strengthens the family unit (Walsh, 1996). There is a correlation between resilience, social networks and physical health. Social support, both emotional and real, was found to increase resilience. Both family and friends were identified as important sources of support in their relationship with ketahana (Bennett, 2015). The dynamics of adaptation in the family really depend on the vulnerability of the situation they experience. Family groups with informal sector workers are the groups most vulnerable to obstacles to family resilience, so that economic, psychological and health resilience needs to be supported by family strength (Casmini, 2020). Family resilience can be realized if each family member can transmit positive energy and adaptation to the various influences that come. There are 3 minimal aspects of family resilience such as physical resilience which includes the needs for clothing, food, shelter, education, and health 2) social resilience oriented to religious values, effective communication, and family commitment, 3) psychological resilience which includes the ability to overcome problems, emotional control, self-concept, and care for family members (Uyun Muhamad, 2020). Family resilience can be realized by fulfilling the basic needs of individuals in the family and supported by the strength of the spiritual and emotional conditions of each family member, so that a family resilience is formed because their physical, social, and emotional needs are met and well formed. The aspect of family resilience is slightly more complex than the aspect of individual resilience, because it is related to the bond between individuals in the family, where the family has to perform family functions such as compassion, protection, reproduction, socialization, education, economy, and environmental development (Witono, 2020). Family resilience is supported by the fulfillment of the family function of each family member, by providing and receiving affection from family members on numerous occasions, obtaining protection from every family member both inside and outside his ward, creating a sense of security and comfort. The education of each family member is well monitored, the family economy is stable, so it is able to provide benefits to the people around them as a function of environmental development. In principle, the aspects that can be observed in analyzing welfare, including the dimensions: income, expenditure for consumption, employment status, health conditions, and the ability to access and utilize basic needs (such as water, sanitation, health care and education) (Sunarti, 2006). Fulfillment of these functions requires good commitment and habituation of each family member in order to realize family resilience.

The following is a graph of the resilience of urban poor families in Bandung City:

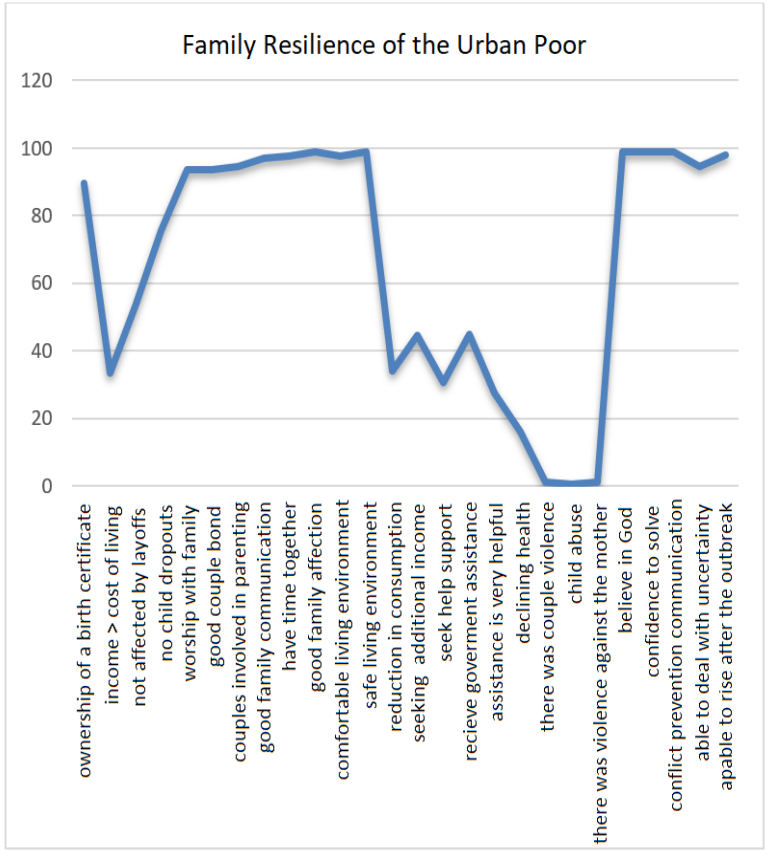

Figure 3. Family Resilience of the Urban Poor

The percentage of family resilience conditions set out in the chart above shows the largest percentage results on indicators of good family affection, a safe living environment, belief in God Almighty, belief in solving problems, and communication that can prevent conflict, respectively $99 \%$. This shows that the function of the family as an affectionate giver is done well by poor families in Bandung. The indicator that the public felt able to rise after the outbreak by $98 \%$. Family members who had shared time is $97.5 \%$, lived in a comfortable place is $97.5 \%$ and mantain good communication with family members is $97 \%$. Poor families in Bandung perform good communication function between family members, meaning that their social resilience is quite good. Parents' negative influence increased compared to the pre-pandemic period, uncertainty intolerance or pandemic-related characteristics (i.e. living surface, income, relatives, working hours at home, helping children attend school and contact with COVID-19 patients at work) were associated with increasing parental negativity during COVID-19 (Janssen et al., 2020). A total of 
94.5\% of married couples are involved in parenting and are able to deal with uncertainty. Indicators of worship together with family and the bond of married couples are well established each get $93 \%$. The social resilience aspect oriented towards religious values is done optimally by poor families in Bandung. In addition, families in Bandung are also quite orderly in terms of administration, as many as $89.5 \%$ of poor families have birth certificates. In this pandemic, $75.5 \%$ of children in Bandung do not dropouts. The function of education in the family is also quite well done by families in Bandung, they are able to maintain their children to continue to receive education even though the situation is quite difficult. Because as many as $46 \%$ of families in Bandung are affected by layoffs, almost half the number of poor families in Bandung are experiencing work laid off. Socially, the pandemic has resulted in significant labor market shocks. In addition, subsequent economic shocks are likely to further impact the quantity and quality of employment, as well as affect vulnerable groups such as migrant and unskilled workers who may not adapt to virtual work arrangements (Lenzen et al., 2020). However, $44.5 \%$ of them are still trying to find additional income. A total of $45 \%$ of families receive social assistance from the government. Therefore, 34\% of families make a reduction in food consumption. Greater income conditions are compared to spending on just $33.5 \%$ of families, meaning most poor families try not to be too consumptive, their spending adjusted for their income. 30.5\% of families seek support from neighbors or relatives, $27.5 \%$ of them feel the assistance received is very helpful to them. The COVID19 pandemic did cause people's economic condition to deteriorate, so people expect help from others, especially from the government (Tapung et al., 2020). These things caused $16 \%$ of family health in Bandung to decline. Unexpected negative events such as violence against spouses, children or mothers are very low at only $0.5-1 \%$.

The key factors of resilient family include: positive outlook, spirituality, family member agreement, flexibility, family communication, financial management, family time, shared recreation, routines and rituals, and environmental support (Black \& Lobo, 2008). The above results show that the resilience of families in Bandung is in good enough, the main factors of resilient families have started to be applied by poor families in Bandung City, so that their resilience is supported by a good internal family climate and good environmental conditions. However, the things that make the condition of family resilience in Bandung quite burdensome are due to external factors, especially economic factors. The level of family resilience is determined by individual and community behavior. Those who have a good understanding of this will be able to survive the changes (Witono, 2020). The concept of family resilience refers to the family as a functional system, influenced by events and social contexts that are very stressful, and in turn, facilitates the positive adaptation of all members and strengthens the family unit (Walsh, 1996). Some families are more vulnerable to pandemics than others, based on preexisting vulnerabilities, such as low income families, mental health and / or special needs, and / or experiences of racism or marginalization (Prime et al., 2020). Psychosocial support for children and families is the most preferred option for solutions to problems raised in family relationships (healthy parenting practices) during the COVID-19 pandemic (Kallciu et al., 2020). Family welfare is also positively influenced by the component of marriage satisfaction, the component of family interaction, the application of family time management, and the husband's education; but it is negatively affected by family income and husband's age (Sunarti et al., 2020). Increasing the resilience of a prosperous family can be carried out through the optimization of family functions, especially economic functions, socialization and education functions, love functions, and reproductive functions (Sunarti et al., 2003).

\section{Community Resilience}

Individual risk factors that underlie the risk of social inequality and affect social stability, therefore community resilience needs to be sought both within the city / district level and within the scope of the country, because of the risk of poverty, urbanization, and social cohesion. (Jacob et al., 2020). Resilience is constructed from the impact of positive process outcomes on the level of individuals, families, and communities in facing of discomfort. Community resilience is the result of reflection of individuals and unique competencies in managing adaptive responses to devastating situations (Rogers et al., 2017). Community resilience is the result of synergy from various units in the community in a good and sustainable way. This synergy forms patterns that empower one family to another. The condition of community resilience in Bandung City during the COVID 19 pandemic is illustrated in the Figure 4. 


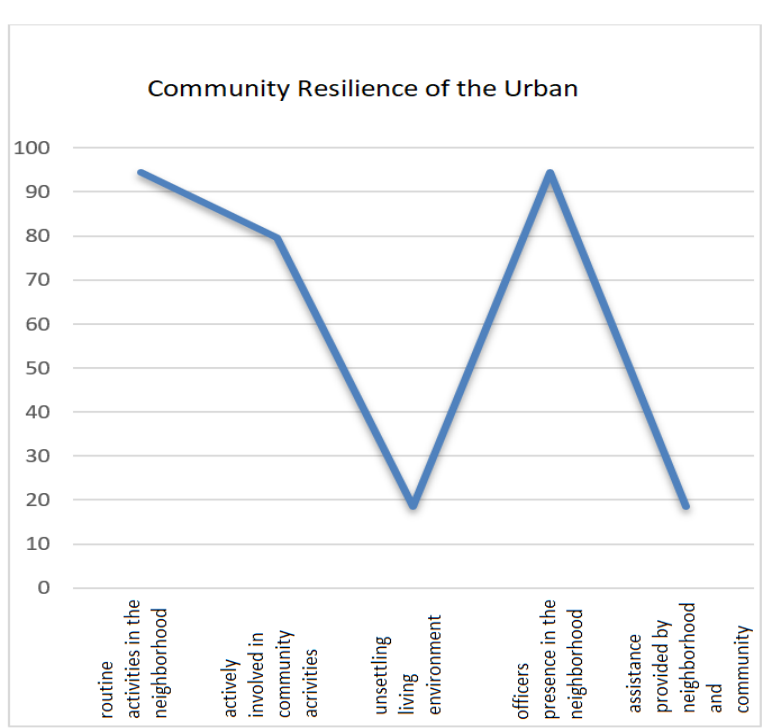

Figure 4. Community Resilience of the Urban Poor

The Figure 4 shows the results of data processing from the aspect of community resilience. The highest percentage was obtained by the factor of routine activities in the neighborhood and the presence of officers in the neighborhood of $94.5 \%$. As many as $79 \%$ of the community is active in community activities. The lowest indicator is in the unsettling living environment and the assistance from neighbors and the community is only $18.5 \%$.

These results indicate that community resilience is strongly driven by the factor of community involvement in both community development activities and security activities in the community. Managing the various disruptions caused by this outbreak and ensuring resilience is important and needs to be pursued (Chowdhury et al., 2020). Community resilience is supported by family resilience because it will create a harmonious pattern between family relationships and social units such as neighbors, economic, political, legal, religious, and other institutions. This will also create harmony with the system of values and norms that apply in society (Witono, 2020). COVID-19 has shown that the protection and welfare of human life and efforts to meet the necessities of life in vulnerable conditions are prerequisites for the future of sustainable development (Etienne et al., 2020). With these challenges, it is hoped that the impact of a pandemic will provide many opportunities that can bring new insights, inspiration for life and community life (Buheji, 2020). The alternative to working from home is becoming increasingly competitive with many people and even organizations / organizations trying to survive are struggling. Therefore, it is necessary to find a new normal role as this is a temporary game that should try to deal with the unstable $3 \mathrm{~F}$ around us:
Family, Finances and Freedom (Buheji, 2020). The synergistic relationship between the system of values and norms in society forms a good resilience of society because it builds a mutually supportive relationship and builds up one another.

\section{CONCLUSION}

The resilience of individuals in poor society during the COVID-19 Pandemic was dominated by the factors of spirituality and strong optimism that emerged from the individuals. This individual's resilience is simultaneous with the resilience of poor families, factor of spirituality and optimism became the main supporters of family resilience during the COVID-19 Pandemic, this makes the community capable to perform family functions well even in deteriorating conditions. However, the factors that reduce family resilience such as economic and psychological factors are also quite influential. Community resilience, which is an accumulation of individual resilience and family resilience, is in quite a good condition with the main supporting factor such as the involvement of individuals in community development activities both in the security, social, and religious fields. This can enable each individual of the families in the community to strengthen each other so that community resilience emerges.

\section{REFERENCES}

Antonio, M., Carriedo, A., Cecchini, A., \& Fern, J. (2020). Resilience and physical activity in people under home isolation due to COVID-19: A preliminary evaluation. Mental Health and Physical Activity, 19 (January).

Barua, Z., Barua, S., Aktar, S., Kabir, N., \& Li, M. (2020). Effects of misinformation on COVID-19 individual responses and recommendations for resilience of disastrous consequences of misinformation. In Progress in Disaster Science (p. 100119).

Barzilay, R., Moore, T. M., Greenberg, D. M., DiDomenico, G. E., Brown, L. A., White, L. K., Gur, R. C., \& Gur, R. E. (2020). Resilience, COVID-19-related stress, anxiety and depression during the pandemic in a large population enriched for healthcare providers. Translational Psychiatry, 10(1).

Bennett, K. M. (2015). Emotional and personal resilience through life Future of an ageing population: evidence review through life. Government Office for Sciene. 
Black, K., \& Lobo, M. (2008). Family Resilience Factors. Journal of Family Nursing, 14(1), 33-55.

Buana, D. R. (2020). Analisis Perilaku Masyarakat Indonesia dalam Menghadapi Pandemi Virus Corona (Covid-19) dan Kiat Menjaga Kesejahteraan Jiwa. SALAM: Jurnal Sosial Dan Budaya Syar-I, 7(3).

Buheji, M. (2020). Forward from "Editor in Chief": The New Normal-A New Era Full of Inspiration and Resilience after COVID-19. International Journal of Inspiration \& Resilience Economy, 2020(2), 0-0.

Casmini. (2020). Read the reality of family resilience in facing pendemics Covid-19 in Indonesia. International Journal of Psychosocial Rehabilitation, 24(10), 4354-4365.

Chowdhury, M. T., Sarkar, A., Saha, P. K., \& Anik, R. H. (2020). Enhancing supply resilience in the COVID-19 pandemic: a case study on beauty and personal care retailers. Modern Supply Chain Research and Applications, ahead-of-p(ahead-ofprint), 143-159.

CNBC. (2020). Corona RI 17 Juli, Positif Tambah 1.462 Sembuh 1489. Diakses pada 21 September 2020 dari https://www.cnbcindonesia.com/news/202007171 04959-8-173472/corona-ri-17-juli-positif-tambah1462-sembuh-1489-orang

Coller, R. J., \& Webber, S. (2021). COVID-19 and the Well-being of Children and Families. PEDIATRICS, 146(4).

Dani, J. A., \& Mediantara, Y. (2020). Covid-19 dan Perubahan Komunikasi Sosial. Persepsi: Communication Journal, 3(1), 94-102.

Detik.com. (2020). Arti PSBB dan 7 Kegiatan yang Dibatasi. Diakses pada 21 September 2020 dari https://news.detik.com/berita/d-4975108/artipsbb-dan7-kegiatan-yang-dibatasi

Distelberg, Brian J., Martin A'verria Sirkin, Borieux, Moosgar and Oloo, Winetta A. (2015). Multidimensional Family Resilience Assessment: The Individual, Family, and Community Resilience (IFCR) Profile, Journal of Human Behavior in the Social Environment, 25(6):552-570,

Eachus, P. (2014). Community Resilience: Is it greater than the sum of the parts of individual resilience? Procedia Economics and Finance, 18(September), 345-351. https://doi.org/10.1016/S2212-5671(14)00949-6

Eshel, Y., \& Kimhi, S. (2016). Determinants of individual resilience following missile attacks: A new perspective. Personality and Individual Differences, 95, 190-195.
Etienne, C. F., Fitzgerald, J., Almeida, G., Birmingham, M. E., Brana, M., Bascolo, E., Cid, C., \& Pescetto, C. (2020). COVID-19: Transformative actions for more equitable, resilient, sustainable societies and health systems in the Americas. $B M J$ Global Health, 5(8), 1-4.

French Red Cross. (2008). Self-Protection with Children in the Community - STATE OF THE ART. 183.

https://www.coe.int/t/dg4/majorhazards/ressources /virtuallibrary/materials/France/Etat de l'art F.pdf

Gogo, A., Osta, A., Mcclafferty, H., \& Rana, D. T. (2019). Culivating a way of being and doing: Individual strategies for physician well being and resilience. Current Problems in Pediatric and Adolescent Health Care, 100663. Hidayatullah, D. R., Darmawan, A., \& Kallidumban, S. (2020). Finding the strategy after corona crisis: the new normal and resilient economy growth in indonesia. 3(1), 64-79.

Ho, C. S., Chee, C. Y., \& Ho, R. C. (2020). Mental Health Strategies to Combat the Psychological Impact of COVID-19 Beyond Paranoia and Panic. Annals of the Academy of Medicine, Singapore, 49(1), 1-3.

Hooper, L. M. (2017). Individual and Family Resilience: Definitions, Re- search, and Frameworks Relevant for All Counselors. The Alabama Counseling Association Journal, 35(1), 19-26.

Irawaty, D. K. (2020). Pengelolaan Keuangan Keluarga Pada Era Pandemik Covid-19 Pengelolaan Keuangan Keluarga Pada Era Pandemik Covid-19 (Issue April). Direktorat Pemberdayaan Ekonomi Keluarga Badan Kependudukan dan Keluarga Berencana Nasional.

Isaacs, S. A., Roman, N., \& Carlson, S. (2020). Fostering Family Resilience: A Community Participatory Action Research Perspective. Child Care in Practice, 26(4), 358-372.

Jacob, C. M., Briana, D. D., Di Renzo, G. C., Modi, N., Bustreo, F., Conti, G., Malamitsi-Puchner, A., \& Hanson, M. (2020). Building resilient societies after COVID-19: the case for investing in maternal, neonatal, and child health. The Lancet Public Health, 5(11), e624-e627.

Janssen, L. H. C., Kullberg, M. L., Verkuil, B., van Zwieten, N., Wever, M. C. M., van Houtum, L. A. E. M., Wentholt, W. G. M., \& Elzinga, B. M. (2020). Does the COVID-19 pandemic impact parents' and adolescents' well-being? An EMAstudy on daily affect and parenting. PLOS ONE, 15(10 October), 1-21. 
Kallciu, A., Capani, B., Selmani, F., \& Semini, I. (2020). Impact assessment of the COVID-19 outbreak on wellbeing of children and families in Albania. Report: Global Vision.

Kasdi, A., \& Saifudin, S. (2020). Resilience of Muslim Families in the Pandemic Era: Indonesian. Jurnal Penelitian, 17(1), 81-94.

Kimhi, S., Marciano, H., Eshel, Y., \& Adini, B. (2020). Recovery from the COVID-19 pandemic: Distress and resilience Shaul. International Journal of Disaster Risk Reduction, January.

Lenzen, M., Li, M., Malik, A., Pomponi, F., Sun, Y. Y., Wiedmann, T., Faturay, F., Fry, J., Gallego, B., Geschke, A., Gómez-Paredes, J., Kanemoto, K., Kenway, S., Nansai, K., Prokopenko, M., Wakiyama, T., Wang, Y., \& Yousefzadeh, M. (2020). Global socio-economic losses and environmental gains from the coronavirus pandemic. PLoS ONE, 15(7 July), 1-13.

Luthar, S. S., Ebbert, A. M., \& Kumar, N. L. (2020). Risk and resilience during COVID-19: A new study in the Zigler paradigm of developmental science. Development and Psychopathology, 1-16.

Marpaung, E. W. B. H., Adrian, L., \& Putri, S. A. (2020). Pandemi COVID-19: Dampak SosialEkonomi, Tantangan, dan Potensi Solusi. Demografi Sosial, May, 1-16.

Navarro-Rivera, J., \& Kosmin, B. A. (2013). Surveys and questionnaires. The Routledge Handbook of Research Methods in the Study of Religion, 395420.

Prime, H., Wade, M., \& Browne, D. T. (2020). Risk and resilience in family well-being during the COVID-19 pandemic. American Psychologist, $75(5)$, 631-643. https://doi.org/10.1037/amp0000660

Pusicov. (2020). Total Kasus COVID 19 di Kota Bandung. Diakses pada 21 September 2020 https://covid19.bandung.go.id/

Ramadhana, M. R. (2020). Mempersiapkan Ketahanan Keluarga Selama Adaptasi Kebiasaan Baru Di Masa Pandemi Covid-19. In Jurnal Kependudukan Indonesia (Vol. 2902).

Rogers, M. B., Amlôt, R., \& Rubin, G. J. (2017). What we do mean by Community Resilience? Define in the Literature. PLOS Currents Disasters, 1 , $1-35$.

Salin, M., Kaittila, A., Hakovirta, M., \& Anttila, M. (2020). Family Coping Strategies During Finland ' s COVID Lockdown. Sustainibility, 12(9133).

Sunarti, E. (2006). Indikator Keluarga Sejahtera: Sejarah Pengembangan, Evaluasi, dan Keberlanjutannya. Bogor: Institut Pertanian Bogor
Sunarti, E., Kamilah, D., Almas, H., \& Pitriani, S. (2020). Family Subjective Well-Being of Health Workers Women During The Covid-19 Pandemic. Journal of Family Sciences, 05(02), 103-120.

Sunarti, E., Syarief, Hidayat, Megawangi, R., Hardiansyah, Saefuddin, A., \& Husaini. (2003). Measurement of Family Strength. Media Gizi \& Keluarga, 27(1), 1-11.

Tapung, M.M, Regus, M., Payong, R.M., Rahmat, S.T. Dan Jelahu, F. . (2020). Bantuan Sosial Dan Pendidikan Kesehatan Bagi Masyarakat Pesisir Yang Terdampak Sosial-Ekonomi Selama Patogenesis Covid-19 Di Manggarai. Transformasi: Jurnal Pengabdian Masyarakat, 16(1), 12-26.

Tsai, J., \& Wilson, M. (2020). COVID-19: a potential public health problem for homeless populations. The Lancet Public Health, 5(4), e186-e187. Uyun, M. (2020). Ketahanan Keluarga dan Dampak Psikologis dimasa Pandemi Global, Yogyakarta: Webinar Program Doktor Psikologi Pendidikan Islam UMY.

Vinkers, C. H., van Amelsvoort, T., Bisson, J. I., Branchi, I., Cryan, J. F., Domschke, K., Howes, O. D., Manchia, M., Pinto, L., de Quervain, D., Schmidt, M. V., \& van der Wee, N. J. A. (2020). Stress resilience during the coronavirus pandemic. European Neuropsychopharmacology, 35, 12-16.

Wahyudi, A., Partini, S., \& Dahlan, U. A. (2018). Factors Affecting Individual Resilience. Advances in Social Science, Education, Anf Humanities Research, 173(Icei 2017), 21-22.

Walsh, F. (1996). Special Section Family Resiliance: A Concept and Its Application The Concept of Family Resilience: Crisis and Challenge THE CONCEPT OF RESILIENCE Research on Individual Resilience. Fam Proc, 35(October 1996), 261-281.

Witono. (2020). COVID-Partisipasi masyarakat dalam ketahanan keluarga. Jurnal Masyarakat Mandiri, 4(3), 396-406.

Yates, T. M., Tyrell, F. A., \& Masten, A. S. (2015). Resilience Theory and the Practice of Positive Psychology From Individuals to Societies. Positive Psychology in Practice: Promoting Human Flourishing in Work, Health, Education, and Everyday Life: Second Edition, Id 0951775, 773-788.

Yunus, N. R., Rezki, A., Nabi, K., Saw, M., Wabah, M., \& Menular, P. (2020). Kebijakan Pemberlakuan Lock Down Sebagai Antisipasi Penyebaran Corona Virus Covid-19. Jurnal Sosial Dan Budaya Syar'i, 7(3), 227-238. 